\title{
ESL Teachers' Intention in Adopting Online Educational Technologies during COVID-19 Pandemic
}

\author{
Kelvin Yew Kai Wen ${ }^{1}$ \\ Kim Hua, $\operatorname{Tan}^{2 \rtimes(\mathbb{D})}$
}

${ }^{\prime}$ Faculty of Education, Universiti Kebangsaan Malaysia, Malaysia.

Email: kielvin.ykw@hotmail.com Tel:0147229212

${ }^{2}$ Faculty of Social Sciences and Humanities, Universiti Kebangsaan Malaysia, Malaysia.

Email:kimmy@ukm.edu.my Tel:01927s5440

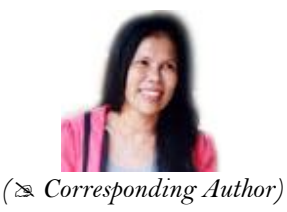

( Corresponding Author)

\begin{abstract}
The COVID-19 pandemic affected many countries across the globe tremendously. One of the consequences of this pandemic was the closure of educational institutions to curb the spread of the virus. In Malaysia, the Ministry of Education (MOE) encouraged teachers to adopt online educational technologies, such as Google Classroom, in executing teaching and learning processes during the pandemic. However, the sudden transition of the nature of education required teachers to prepare themselves to carry out online education in an instant. Past studies revealed that ICT competence, infrastructure and online resources and working environment affect teachers' usage of online educational technologies in their teaching. This study examined the relationship amongst these three factors and teachers' intention to adopt online educational technologies. This study also identified the most significant factor that affects teachers' behavioural intentions. A total of 153 Malaysian ESL teachers participated in this study via a survey questionnaire. Findings revealed that although the working environment was moderately correlated with teachers' behavioural intentions, the other two factors were strongly correlated with teachers' behavioural intentions. This study found accessibility to infrastructure and online resources to be the most significant factors that affected teachers' behavioural intentions.
\end{abstract}

Keywords: Behavioural intention, COVID-19 Pandemic, ESL teachers, ICT competence, Infrastructure and resources, Online educational technology, Working environment.

Citation | Kelvin Yew Kai Wen; Kim Hua, Tan (2020). ESL Teachers' Intention in Adopting Online Educational Technologies during COVID-19 Pandemic. Journal of Education and e-Learning Research, 7(4): 387-394.

History:

Received: 4 September 2020

Revised: 25 September 2020

Accepted: 19 October 2020

Published a Novenbr

Picensed: This work is licensed under a Creative Commons

Licensed: This work is

Publisher: Asian Online Journal Publishing Group
Acknowledgement: Both authors contributed to the conception and design of the study.

Funding: The authors received financial support for the research and authorship of this article from the Ministry of Higher Education Research Grant coded FRGS/1/2018/SS09/UKM/02/1.

Competing Interests: The authors declare that they have no conflict of interests.

Transparency: The authors confirm that the manuscript is an honest, accurate, and transparent account of the study was reported; that no vital features of the study have been omitted; and that any discrepancies from the features of the study have been omitted
study as planned have been explained. study as planned have been explained.
Ethical: This study follows all ethical practices during writing.

\section{Contents}

1. Introduction ...

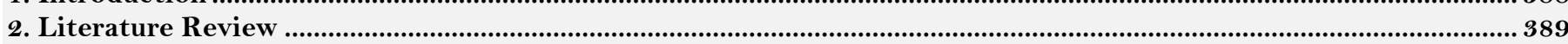

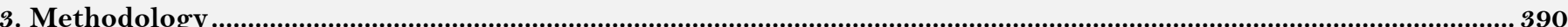

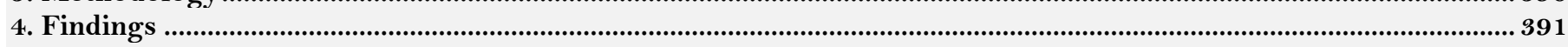

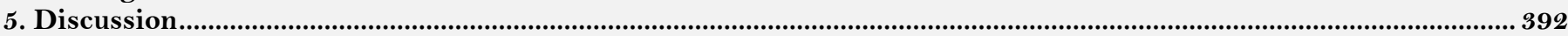

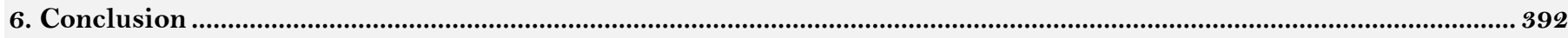

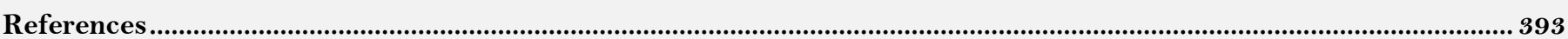




\section{Contribution of this paper to the literature}

This study highlights factors that correlated with teachers' behavioural intention in adopting online teaching and learning tools during the COVID-19 pandemic. The factors of accessibility of infrastructure and online resources were significant and preceded the factor of working environment. With the findings, policymakers will be able to modify the teaching and learning context during the implementation of emergency remote teaching and carry out necessary actions to improve the teaching and learning process during a pandemic. Clearly online teaching has different priorities during a pandemic than was before.

\section{Introduction}

Online educational technologies have been flourishing in the education system, especially in the 4th Industrial Revolution (4th IR). The advancement of technologies happening in the 4th IR created significant impacts on various aspects of human life, which includes business, governance and people's lifestyle. Consequently, Education 4.0 was established in response to the impact brought by the 4th IR on the education system worldwide.

Education 4.0, which is an advanced version of Education 3.0, emphasises innovation-producing education (Harkins, 2008). Hussin (2018) stated that education nowadays should equip learners with the skills to identify the source of the knowledge, instead of spoon-feeding them with the skills and knowledge needed to pass the examinations. Students must learn through collaborative learning and teachers or instructors act as the facilitators in guiding the learners in their learning experience. In addition, one of the trends in Education 4.0, as proposed by Fisk (2017) is the flexibility of the learning process. Leaners should be able to learn without the constraints of time and space.

To fulfil the needs of Education 4.0, many online educational technologies are being developed to facilitate and advance learners' learning processes, for example, Google Classroom, Schoology, Moodle and Frog VLE. These are virtual classrooms developed to organise file and resource sharing amongst teachers and students. By using virtual classrooms, teachers can upload any relevant learning materials and assignments, and students can access all of the materials and submit their assignments through the platforms. Ultimately, with the development of mobile phone applications for certain virtual classrooms, teachers and students can access the platform whenever and wherever they choose.

In addition to the educational revolution, the COVID-19 pandemic is another force that drives the adoption of online teaching and learning amongst teachers. In December 2019, the COVID-19 outbreak began to affect the global economy and people's lifestyles (Atkeson, 2020) including education. To curb the spread of COVID-19, many educational institutions worldwide closed. Based on statistical data provided by UNESCO (2020) the global closure of the schools affected over $60 \%$ of the student population.

In response to this challenge, countries, such as Malaysia, South Korea and Indonesia implemented online teaching and learning in their educational institutions (Crawford et al., 2020). The nature of online education during the pandemic differs from that before the pandemic. Online education, which is developed from traditional distance learning, aims to provide educational opportunities for students who are geographically distant via online technology (Moore, Dickson-Deane, \& Gaylen, 2011). Proper planning before the introduction of online courses is crucial because it influences their effectiveness (Leist \& Travis, 2010). The online courses introduced by educational institutions undergone continual validation and evaluation to ensure course effectiveness (Baldwin, Ching, \& Hsu, 2018).

The transition to online education during the pandemic serves a different purpose than normal online education does. The term 'emergency remote teaching' (ERT) was introduced to describe the online teaching mode during the pandemic. ERT aims to provide makeshift access to instruction and instructional supports during the pandemic (Hodges, Moore, Lockee, Trust, \& Bond, 2020). The created online courses are not meant to comprise a long-term program in the education system. Therefore, educators and policymakers must not view ERT as parallel to online distant education, which is implemented before the pandemic as designing the learning system with the incorrect assumption will cause the system to be vulnerable to errors along the way (Bozkurt \& Sharma, 2020).

In Malaysia, the integration of online educational technologies in the classroom has been implemented since the establishment of 1BestariNet Project in 2012. The MOE's aspiration to utilise Information and Communication Technology (ICT) to enhance the education system across Malaysia was reflected in the Malaysia Education Blueprint 2013-2025 (Ministry of Education Malaysia, 2013). Based on the blueprint, the infusion of ICT in the education system promotes students' autonomy in their learning process as they are be able to learn in their own pace and access a wide range of learning contents through the plethora of online courses and platforms. The ICT also benefits teachers as they will have access to online teaching resources, which they can use to improve their teaching process.

In July 2019, the MOE discontinued the contract with Frog VLE as Google Classroom was chosen as a replacement for Phase 2 of 1 BestariNet project (Ministry of Education Malaysia, 2019). In June 2020, the MOE launched an online learning platform, the Digital Educational Learning Initiative Malaysia (Delima). Delima is the rebranding of the Google Classroom introduced by the MOE, with the addition of applications from two major IT corporates, Microsoft and Apple. Delima was introduced to allow teachers to share the learning resources for online teaching and learning besides preparing students to be competent in the future global market (Menon, 2020).

The Malaysian government issued the Movement Control Order (MCO) on March 18, 2020 as an initiative to prevent the spread of the outbreak in the country (Bunyan 2020). As the MCO took place, all private and government educational institutions were closed as well. To sustain teaching and learning processes during the MCO period, the MOE created guidelines for the teachers to execute teaching and learning processes during the outbreak. The MOE encouraged teachers to use the online educational technologies introduced by the ministry, such as the Google Classroom and Microsoft Team, to conduct online education (Ministry of Education Malaysia, 2020a). As the MOE realised the challenges faced by some students with limited access to the Internet, they also rolled out the Educational TV Programme, which is a form of delivering learning content via TV broadcasting 
(Ministry of Education Malaysia, 2020b). Given that not all teachers and students were equipped with the facilities to conduct online teaching and learning processes, the MOE allowed the school administration to decide on the methods of conducting teaching and learning processes during the MCO periods.

As the ERT was not properly taught before the implementation, challenges arose along the way when the teachers were exploring the use of online educational technologies in delivering the lessons. Teachers might not have access to adequate facilities and online resources to carry out the lessons. They might also face difficulties due to the limited technological knowledge to utilise online educational technologies properly. These challenges will affect teachers' readiness, which in turn affect the effectiveness of the students' learning process (Lynch, Smith, Provost, Yeigh, \& Turner, 2017). Therefore, this study examined the relationship between the factors (i.e. teachers' self-perceived ICT competence, the accessibility to infrastructure and online resources and the suitability of working environment) and teachers' intention to adopt online educational technologies in the future. Ultimately, this study also identified the factor that significantly impacts teachers' behavioural intention the most.

\section{Literature Review}

We first provide an overview of the types of online educational technologies used in different modes of curriculum. We then review three major factors that were cited as the elements that affect teachers' adoption of online educational technologies during the COVID-19 pandemic.

\subsection{Online Educational Technologies}

Allen and Seaman (2016) defined online learning as a course where most or all of the content is delivered online. However, they also stated other relevant courses, which include the adoption of different levels of online educational technologies, namely, blended and web facilitated courses.

Blended learning is the integration of face-to-face and online instruction (Graham 2013). An example of blended learning is the flipped classroom approach, whereby the presentation of the content has turned to home activity, and the activity that is traditionally seen as homework has turned into classroom activities. The integration of online educational technologies happens when teachers deliver the learning content through the online application, and students are responsible for governing their learning (Lin \& Hwang, 2019).

The web-facilitated course uses web-based technology to facilitate face-to-face interaction Allen and Seaman (2016). In this course, teachers may use a learning management system (LMS) as a platform to provide students with the syllabus and assignment. Compared with the previous two types of courses, the web-facilitated course uses a minimum amount of online educational technologies in the lessons. Despite the different proportion amount of content delivered online, teachers or instructors in these three types of courses adopted some online educational technologies in delivering the learning contents.

As online education attracts growing attention, many online educational technologies were developed in recent years. Online educational technologies are any program, app, or technology that can be accessed via an internet connection (Saadé \& Al-Sharhan, 2015). These tools are used to refine teachers' competence at presenting information and students' ability to access that information.

One of the examples of online educational technologies is Google Classroom, a virtual classroom that helps teachers save time, keeps the class and enhances the interpersonal communication amongst students (Iftakhar, 2016; Omar, Amir, \& Mohamad, 2018). In addition, there exist online game-based learning tools, such as Kahoot, Quizizz, Quizlet and Plickers that help teachers assess students' learning progress in a fun environment. These online game-based learning tools improve the effectiveness of students' learning process (Chaiyo \& Nokham, 2017; Tan. \& Tan, 2020; Zarzycka-Piskorz, 2016). Some social media platforms and applications, such as Twitter, Facebook, WhatsApp, Snapchat and Instagram are adopted by teachers in delivering classroom content and as tools for students to practice and present the skills they learned (Hamat \& Hassan, 2019). There exist numerous online educational technologies that teachers can adopt to improve teaching and learning processes effectivity.

\subsection{Factors that Affect Teachers' Readiness in Adopting Online Educational Technologies 2.2.1. Teachers' ICT Competence}

Teachers must acquire three types of knowledge to adopt online educational technologies in the lesson effectively. These are content, pedagogy and technology knowledge, as proposed in the Technological Pedagogical Content Knowledge (TPACK) framework (Koehler \& Mishra, 2009; Philip, Tan, \& Jandar, 2019; Tan, Philip, \& Jandar, 2019). During the teacher training education program, all pre-service teachers are equipped with content and pedagogy knowledge.

However, since e-learning began to be a focus in the early 21 st century, not all in-service teachers were exposed to technological knowledge during their teacher training programs. Thus, some teachers lack confidence in adopting online educational technologies in the lessons because they have limited TPACK knowledge (Benjamin, 2017; Kandasamy \& Shah, 2013; Razak., Alakrash, \& Sahboun, 2018). The lack of self-competence is also caused by insufficient in-service training, which will be explained separately in the latter part of this section (Merç 2015). Teaching using traditional approaches and teaching using educational technology require different sets of knowledge in teachers. Lacking any of the knowledge will hinder teachers from incorporating online educational technologies in the lessons.

In spite of the existence of online education before the COVID-19 pandemic, some teachers could not cope with ERT due to their limited knowledge of education technology (Sahu, 2020). This phenomenon affected online education effectivity because teachers needed to be equipped with specific skills and knowledge to design and carry out effective online education (Crawford et al., 2020). Thus, a series of special training to teachers were provided by the government to equip teachers with the proper knowledge and skills in using online educational technologies during the COVID-19 pandemic (Cheng, 2020). However, it was stated by Zhang, Wang, Yang, and Wang (2020) that the special training provided might have had a minimal effect on teachers' ability. Boulton (2014) proved that the effectiveness of an in-service training program was determined by teachers' self-efficacy and the duration of the program. These factors are what the government examines when planning training programs for teachers. 


\subsubsection{Infrastructure and Online Resources}

The importance of proper infrastructure and online resources is undeniable in the teachers' use of online educational technologies during lessons. To encourage teachers to adopt online teaching and learning resources, schools play a vital role in preparing the necessary infrastructure teachers need, such as computers and smartboards that are connected to the Internet.

However, the lack of funding from schools precluded teachers' access to proper tools (Salem \& Mohammadzadeh, 2018). Classrooms that are not designed to comply with 21 st-century learning will prevent teachers from using online educational technologies due to the lack of power resources and fixed seating arrangements (Benjamin, 2017). Some schools provide limited technological tools for teachers. Therefore, they must wait for their turn, causing them to resort to traditional teaching approaches (Muslem, Yusuf, \& Juliana, 2018). Even when teachers are motivated to integrate online educational technologies in the lessons, the lack of infrastructure and resources forced them to abandon the idea (Razak. et al., 2018). Thus, schools play an essential role in preparing the necessary infrastructure and resources for teachers because these are one of the most significant factors that affect teachers' readiness in adopting online educational technologies.

Given that online education technology is the main medium for teachers to deliver teaching instruction in ERT, the availability of infrastructure and online resources emerged as an important factor that affects teachers' readiness in adopting online educational technologies. As opposed to online education before the COVID-19 pandemic, teachers had to work from home during the outbreak because all schools and campuses were closing. Consequently, some teachers might not have the proper infrastructure to access online teaching materials at home (Sahu, 2020; Zhang et al., 2020). Owing to the sudden transition to online education during the COVID-19 pandemic, teachers lacked online teaching resources for online education before the COVID-19 pandemic, which supplemented offline lessons (Zhang et al., 2020).

In some countries, the government realised the issue, and exerted efforts towards producing learning resources that can be accessed via online learning platforms or TV networks (Cheng, 2020; Zhou, Li, Wu, \& Zhou, 2020) Given that students studied from home during the outbreak, proper infrastructure was necessary for them to ensure online teaching and learning process effectiveness (Crawford et al., 2020).

\subsubsection{Suitability of Working Environment}

The suitability of the environment is a new factor that affects teachers' readiness to adopt online educational technologies from ERT. Given that a suitable working environment has been associated with one's job satisfaction and performance, teachers need an optimum working environment at home to ensure teaching and learning effectivity (Raziq \& Maulabakhsh, 2015). However, teachers that work from home can be distracted by their housework and childcare (Zhang et al., 2020). If teachers cannot focus on online education, the effectiveness of ERT will be jeopardised.

Social distancing was practised during the pandemic to curb the spread of the COVID-19. However, the pandemic and social distancing took a toll on people's mental health, including that of educators (Galea, Merchant, \& Lurie, 2020; Zhang \& Ma, 2020). Affected mental wellbeing will impact online teaching and learning effectivity.

Based on the previous studies, many factors affect teachers' adoption of educational technologies as an innovation in education. Amongst all of the factors, teachers' ICT competence, accessibility to infrastructure and resources and the suitability of the working environment were selected as the focus of this study as they were mentioned in the studies related to teachers' adoption of online educational technologies during the COVID-19 pandemic. Therefore, these factors must be studied in the context of Malaysia to provide information for local policymakers in making any improvement in the system.

\section{Methodology}

This study used a quantitative research design. This study selected a sample of 153 Malaysian ESL teachers from the primary and secondary schools to participate in the research via accidental sampling. Amongst the 153 participants, 19 of them were male teachers and 134 of them were female teachers. A total of 128 of the participants were teaching at governments primary schools. The rest were 11 government secondary schoolteachers and 14 private secondary schoolteachers. Exactly 69 of the teachers were teaching in urban area schools, whilst 53 and 31 teachers were teaching at suburban and rural area schools, respectively.

The research instrument used in this research was a survey questionnaire, which comprised seven sections, as shown in Table 1. The overview of the survey is shown in Table 1. The first section comprised eight items on teachers' demographic background information. The second section comprised five items that examined teachers' self-perceived ICT competence. This set of items was adopted from Technological Pedagogical Content Knowledge (TPACK) subscales designed by Schmidt et al. (2009).

The third section comprised five items that examined teachers' accessibility to infrastructure and online teaching recourses during the MCO period. The fourth section comprised six items that examined the suitability of teachers' working environment during the MCO period. The fifth section comprised three items that examined teachers' intention to use online educational technologies in the future. This set of items were adopted from the questionnaire designed by Venkatesh and Bala (2008).

The second to fifth sections employed the 7-point Likert scale response mode of (1) Strongly disagree, (2) Disagree, (3) More or Less Disagree, (4) Undecided, (5) More or Less Agree, (6) Agree and (7) Strongly Agree. Cronbach's alpha values of .60 to .95 indicate an acceptable level of reliability (Ursachi, Horodnic, \& Zait, 2015). The Cronbach's alpha values of Sections 2 to 6 of the survey indicated that the survey was reliable. The sixth section comprised three open-ended questions to collect teachers' personal opinions on online teaching and learning processes during the MCO period. 
Table-1. Overview of the survey questionnaires.

\begin{tabular}{|c|c|c|c|}
\hline Section & Title / Variables & Number of Items & Cronbach's Alpha $(\alpha)$ \\
\hline 1 & Demographic background information & 8 & - \\
\hline 2 & Teachers' self-perceived ICT competence & 5 & .85 \\
\hline 3 & Accessibility to infrastructure and online resources & 5 & .84 \\
\hline 4 & Suitability of working environment & 6 & .90 \\
\hline 5 & Behavioural intention & 3 & .65 \\
\hline 6 & $\begin{array}{l}\text { Personal opinion on teaching and learning during } \\
\text { the pandemic }\end{array}$ & 3 & - \\
\hline
\end{tabular}

Source: Instrument adapted from Schmidt et al. (2009) and Venkatesh and Bala (2008).

\section{Findings}

The survey instruments were intended to examine teachers' self-perceived competence, accessibility of infrastructure and online teaching resources, the suitability of the working environment and their behavioural intention to adopt online educational technologies in the future. The mean score of every section of the survey was tabulated in Table 2 .

\begin{tabular}{l|c|c}
\multicolumn{3}{c}{ Table-2. Mean score of every section of the survey. } \\
\hline Sections & Mean & SD \\
\hline Self-perceived ICT competence & 4.97 & 1.19 \\
\hline Accessibility to infrastructure and online teaching resources & 5.49 & 1.18 \\
\hline Suitability of working environment & 4.53 & 1.40 \\
\hline Behavioural intention & 5.22 & 1.14 \\
\hline
\end{tabular}

Based on Table 2 the majority of the participants agreed that they had sufficient access to infrastructure and online teaching resources $($ mean $=5.49, \mathrm{SD}=1.18)$ during the COVID-19 pandemic. They more or less agreed that they possessed sufficient competence (mean $=4.97, \mathrm{SD}=1.19)$ in operating online educational technologies in delivering the teaching contents during the pandemic. They also more or less agreed that their house was a suitable working environment $($ mean $=4.53, \mathrm{SD}=1.40$ ) for them to carry out their responsibilities as teachers during the pandemic. A majority of the participants agreed that they would continue to adopt online educational technologies $($ mean $=5.22, \mathrm{SD}=1.14)$ in future lessons.

Spearman's correlation was conducted to examine the relationship between predictors and teachers' behavioural intention to adopt online teaching technologies in the future. The findings were tabulated in Table 3.

\begin{tabular}{c|c|c|c|c}
\hline \multicolumn{2}{c}{ Table-3. Correlation between the factors and the behavioural intention. } \\
\hline & $\begin{array}{c}\text { Self-perceived ICT } \\
\text { competence }\end{array}$ & $\begin{array}{c}\text { Accessibility to } \\
\text { infrastructure and } \\
\text { online resources }\end{array}$ & $\begin{array}{c}\text { Suitability of } \\
\text { working environment }\end{array}$ \\
\hline \multirow{2}{*}{$\begin{array}{c}\text { Behavioural } \\
\text { intention }\end{array}$} & $\begin{array}{c}\text { Correlation } \\
\text { Coefficient }\end{array}$ & $.604^{* *}$ & $.658^{* *}$ & $.531^{* *}$ \\
\cline { 2 - 5 } & Sig. (2-tailed) & .000 & .000 & .000 \\
\hline Note: **. Correlation is significant at the 0.01 level (2-tailed)
\end{tabular}

Note: ***. Correlation is significant at the 0.01 level (2-tailed).

The findings from the Spearman's correlation indicated that there was a significant strong positive linear relationship between the teachers' self-perceived competence and their behavioural intention $\left[r_{s}(151)=0.604, p<\right.$ .05]. A significant strong positive linear relationship existed between the accessibility to infrastructure and online teaching resources and the behavioural intention $\left[r_{\mathrm{s}}(151)=0.658, \mathrm{p}<.05\right]$. A significant moderate positive linear relationship existed between the suitability of working environment and the behavioural intention $\left[\mathrm{r}_{\mathrm{s}}(151)=.531\right.$, $\mathrm{p}<.05]$.

To determine the factor that most significantly influenced teachers' intention to adopt online educational technologies in the future, a multiple linear regression was conducted. The assumption of collinearity of data, independent errors, normal distribution of errors, homoscedasticity and linearity and non-zero variances was fulfilled. The model of summary of the test was shown in Table 4. All of the independent variables gave 52.4\% contribution that would influence teachers' intention to adopt online educational technologies in the future.

Table-4. Test of significance of regression model.

\begin{tabular}{c|c|c|c}
\multicolumn{4}{|c}{ Table-4. Test of significance of regression model. } \\
\hline $\mathbf{R}$ & R Square & Adjusted R Square & Std. Error of the Estimate \\
\hline $.724^{\mathrm{a}}$ & .524 & .515 & .79333 \\
\hline
\end{tabular}

Table 5 indicates that the test statistic was significant at 0.05 level of significance $\left(\mathrm{F}_{(3,149)}=54.709, \mathrm{p}<.05, \mathrm{R}^{2}\right.$ $=.524, \mathrm{R}^{2}$ Adjusted $\left.=.515\right)$. It revealed that teachers' self-perceived ICT competence, the suitability of working environment and accessibility to infrastructure and online resources could be significant predictors of teachers' behavioural intention.

Table-5. ANOVA for multiple correlation between teachers' self-perceived ICT competence, accessibility to infrastructure and online resources and the suitability of the working environment.

\begin{tabular}{c|c|c|c|c|c}
\hline Model & Sum of Squares & df & Mean Square & F & Sig. \\
\hline Regression & 103.297 & 3 & 34.432 & 54.709 & $.000^{\mathrm{b}}$ \\
\hline Residual & 93.777 & 149 & .629 & & \\
\hline Total & 197.073 & 152 & & & \\
\hline
\end{tabular}

The result of the multiple regression, as shown in Table 6, indicated that the three factors affected teachers' intention to adopt online educational technologies in the future. The most important factor, based on the beta value 
$(\beta)$ of standardised coefficients, was the accessibility to infrastructure and online resources $(\beta=.446)$. This variable was statistically significant at the 0.05 level.

Table-6. Regression analysis summary for the factors predicting the behavioural intention.

\begin{tabular}{l|c|c|c|c|c}
\hline \multirow{2}{*}{ Model } & \multicolumn{2}{|c|}{$\begin{array}{c}\text { Un-standardised } \\
\text { Coefficients }\end{array}$} & $\begin{array}{c}\text { Standardised } \\
\text { Coefficients }\end{array}$ & \multirow{2}{*}{ t } & \multirow{2}{*}{ Sig. } \\
\cline { 2 - 4 } & $\mathbf{B}$ & Std. Error & Beta & & \\
\hline Constant & 1.117 & .330 & & 3.382 & .001 \\
\hline Teachers' self-perceived ICT competence & .202 & .069 & .212 & 2.922 & .004 \\
\hline Accessibility to infrastructure and online resources & .430 & .068 & .446 & 6.290 & .000 \\
\hline Suitability of working environment & .164 & .056 & .202 & 2.922 & .004 \\
\hline
\end{tabular}

\section{Discussion}

The COVID-19 pandemic provided opportunities for teachers to explore the use of online educational technologies in implementing their teaching and learning processes due to the closure of educational institutions. Online educational technologies in Malaysia were previously introduced as a supplementary for face-to-face interactions. During the sudden implementation of Movement Control Order, the Malaysia Ministry of Education had recommended teachers to utilise the available online learning technologies to sustain teaching and learning processes during school closures. Given that complete online education was not entirely planned in Malaysia, many factors could affect teachers' intention to adopt online educational technologies in the future.

\subsection{Relationship between the Factors and Teachers' Behavioural Intention}

The findings from the survey questionnaire indicated that teachers' self-perceived ICT competence and the accessibility to infrastructure and online resources significantly correlated with their intention to adopt online educational technologies in the future.

Teachers' ICT competence was an important element in their efforts to adopt online educational technologies as there was a plethora of online educational tools available online and each of them requires different sets of skills and techniques in the operation. Some of the tools, such as Google Classroom offer different kinds of functions that assist teachers in online education, such as assigning homework, making announcement and organising video conference session. To maximise the use of such tools, teachers must be equipped with a certain level of technological competence to ensure that the online lessons can be carried out smoothly and effectively. The importance of teachers' ICT competence was aligned with several past studies by Benjamin (2017); Kandasamy and Shah (2013) and Razak et al. (2018). The participants of this study were reported to be satisfied with their ICT competence. This may be due to a series of webinars organised by the MOE in helping teachers master the usage of the online educational technologies throughout the MCO period.

The accessibility to infrastructure and online resources was also another variable that affected teachers' intention to adopt online educational technologies significantly. Infrastructure, such as laptops, speakers and stable internet connections are the foundation of any online teaching and learning activity. One of the main reasons that hindered teachers' from adopting online educational technologies was the lack of infrastructure provided at schools (Benjamin, 2017; Muslem et al., 2018).

This issue was caused by the lack of funds and awareness amongst the school administrative teams. As opposed to the traditional face-to-face interaction, teachers had to look for digitised materials in the online teaching and learning process. The MOE created digitised textbooks for the use of all primary and secondary teachers. In addition, other online learning resources existed, such as YouTube videos and online quizzes that were produced by teachers to encourage the adoption of online educational technologies amongst teachers. During the COVID-19 pandemic, teachers had to depend on the infrastructure available at home. The findings of the survey showed that the participants had adequate access to the infrastructure and online resources necessary for them to carry out online teaching.

Meanwhile, the suitability of working environment was moderately correlated with teachers' behavioural intention. As most of the teachers in Malaysia rarely had the opportunity to teach from home, the first experience in this situation might make them feel motivated as their working hours became flexible. However, they might be distracted by other household chores, activities and responsibilities.

\subsection{Most Significant Factor}

Amongst the three factors discussed, the most important factor that affected teachers' intention to adopt online educational technologies was the accessibility of infrastructure and learning resources. In this case, the government and the school administrative team play a significant role in ensuring teachers have sufficient access to tools and materials necessary to sustain the usage of online educational technologies in the future.

Razak. et al. (2018) found that the lack of infrastructure was the main challenge that discouraged teachers from adopting online educational technologies in their lessons. Therefore, besides providing a platform for teachers to interact with students online, the government must provide teachers other necessities, such as laptops, internet connections, headphones and microphones.

Some teachers were unprepared for the online teaching and learning due to the sudden closure of schools (Zhang et al., 2020), especially when it happened in the middle of a school holiday in Malaysia. Although the majority of the participants from this study agreed that they had sufficient access to the infrastructure and teaching resources needed, the majority of the teachers were teaching in urban schools. Teachers who are teaching in rural schools might suffer from weak internet connections.

\section{Conclusion}

The COVID-19 pandemic that terrorised countries across the globe caused a tremendous impact on the education system worldwide. The closure of educational institutions was one of the measures taken by the 
government of many countries to stop the spread of the virus. The sudden closure of schools caused teachers and students to connect through the Internet. In Malaysia, initiatives were made by the MOE to encourage teachers and students to learn through online educational technologies. However, many factors surfaced that affected teachers' intention to adopt online educational technologies in the future. Teachers' self-perceived ICT competence and accessibility to infrastructure and online resources were strongly correlated with teachers' behavioural intention, whilst the suitability of working environment was moderately correlated with teachers' behavioural intention. Amongst all of the factors, the accessibility to infrastructure and online resources are the most important factors that determine teachers' intention to adopt online educational technologies in the future.

Based on the findings of this study, policymakers can consider teachers' ICT competence and their accessibility to infrastructure and online resources in planning the curriculum. Apart from the courses organised, the education system should introduce more webinars to allow more teachers to learn how to use and operate all the online educational technologies. School administrative teams should be aware of the importance of these technologies and ensure that the school culture encourages collaboration amongst teachers in developing their technological skills. The government should provide teachers with the basic necessities for them to perform online teaching and learning effectively, especially for teachers who are teaching and residing in rural areas. The government should always ensure that the internet connection at every school is always stable.

This research, however, is subject to several limitations. First, most of the participants of this study were teaching in urban area schools. Teachers in rural and urban areas school face different types of challenges, especially regarding educational technology (Sundeen \& Sundeen, 2013; Wang, 2013). The infrastructure available and students' technological competence are a few challenges faced by most rural area schoolteachers. The result might not provide a comprehensive view of the situation in Malaysia's education system. Therefore, future research should ensure that the proportion of the participants from rural and urban schools is sufficiently balanced to provide a more comprehensive view.

There exists a lack of comprehensive and tested instrument to assess the effectiveness of the usage of online educational technologies during the pandemic. In this study, we generated the survey questionnaires and tested its validity through a pilot test to ensure research finding validity. However, the lack of a robust instrument may cause researchers to overlook some aspects whilst using the self-created survey questionnaire. This study warrants further research to generate a comprehensive survey questionnaire to assess online education effectivity during the pandemic.

\section{References}

Allen, I. E., \& Seaman, J. (2016). Online report card: Tracking online education in the United States. Massachusetts: Babson Survey Research Group.

Atkeson, A. (2020). What will be the economic impact of Covid-19 in the us? Rough estimates of disease scenarios. NBER Working Paper No. 26867.

Baldwin, S., Ching, Y. H., \& Hsu, Y. C. (2018). Online course design in higher education: A review of national and statewide evaluation instruments. Tech Trends, 62, 46-57. Available at: 10.1007/s11528-017-0215-z.

Benjamin, S. M. (2017). Factors that influence and impede implementation of information communication technology in a secondary school's english language arts classroom: Selected Tobago teachers' perception. Doctoral Dissertation, The University of the West Indies, Jamaica.

Boulton, M. J. (2014). Teachers' self-efficacy, perceived effectiveness beliefs, and reported use of cognitive-behavioral approaches to bullying among pupils: Effects of in-service Training with the I DECIDE program. Behavior Therapy, 45(3), 328-343. Available at: 10.1016 /j.beth.2013.12.004.

Bozkurt, A., \& Sharma, R. C. (2020). Emergency remote teaching in a time of global crisis due to CoronaVirus pandemic. Asian Journal of Distance Education, 15(1), 1-6. Available at: 10.5281/zenodo.3778083.

Bunyan, J. (2020). PM: Malaysia under movement control order from Wed until March 31, all shops closed except for essential services. Retrieved from: https://www.malaymail.com/news/malaysia/2020/03/16/pm-malaysia-in-lockdown-from-wed-until-march-31all-shops-closed-except-for/1847204.

Chaiyo, Y., \& Nokham, R. (2017). The effect of Kahoot, Quizizz and Google Forms on the student's perception in the classrooms response system. Paper presented at the International Conference on Digital Arts, Media and Technology (ICDAMT). Chiang Mai: IEEE.

Cheng, X. (2020). Challenges of 'school's out, but class's on' to school education: Practical exploration of Chinese schools during the COVID19 Pandemic. Science Insigt Edu Front, 5(2), 501-516. Available at: 10.2139/ssrn.3565605.

Crawford, J., Butler-Henderson, K., Rudolph, J., Malkawi, B., Glowatz, M., Burton, R., \& Lam, S. (2020). COVID-19: 20 countries' higher education intra-period digital pedagogy responses. Journal of Applied Learning \& Teaching, 3(1), 1-20. Available at: http://dx.doi.org/10.37074/jalt.2020.3.1.7.

Fisk, P. (2017). The future of learning will be dramatically different, in school and throughout life. Retrieved from: https://www.thegeniusworks.com/2017/01/future-education-young-everyone-taught-together/.

Galea, S., Merchant, R. M., \& Lurie, N. (2020). The mental health consequences of COVID-19 and Physical Distancing: The need for prevention and early intervention. JAMA Intern Med, 180(6), 817-818. Available at: 10.1001/jamainternmed.2020.1562.

Graham, C. R. (2013). Emerging practice and research in blended learning. In M. G. Moore, Handbook of Distance Education (pp. 333-350). New York: Routledge.

Hamat, A., \& Hassan, H. A. (2019). Use of social media for informal language learning by Malaysian University Students. 3L: The Southeast Asian Journal of English Language Studies, 25(4), 68-83. Available at: 10.17576/3L-2019-2504-05.

Harkins, A. M. (2008). Leapfrog principles and practices: Core components of education 3.0 and 4.0. Future Research Quarterly, 24(1), 19-31.

Hodges, C., Moore, S., Lockee, B., Trust, T., \& Bond, A. (2020). The difference between emergency remote teaching and online learning. Retrieved from: https://er.educause.edu/articles/2020/3/the-difference-between-emergency-remote-teaching-and-onlinelearning.

Hussin, A. A. (2018). Education 4.0 made simple: Ideas for teaching. International Journal of Education Eீ Literacy Studies, 6(3), 92-98. Available at: 10.7575/aiac.ijels.v.6n.3p.92.

Iftakhar, S. (2016). Google Classroom: What works and how? Journal of Education and Social Sciences, 3(1), 12-18.

Kandasamy, M., \& Shah, P. (2013). Knowledge, attitude and use of ICT among ESL teachers. Paper presented at the Proceedings of the Global Summit on Education.

Koehler, M., \& Mishra, P. (2009). What is technological pedagogical content knowledge (TPACK)? Contemporary Issues in Technology and Teacher Education, 9(1), 60-70.

Leist, J., \& Travis, J. (2010). Planning for online courses at rural community colleges. New Directions for Community Colleges, 2010(150), 17-25. Available at: https://doi.org/10.1002/cc.401.

Lin, H. C., \& Hwang, G. J. (2019). Research trends of flipped classroom studies for medical courses: A review of journal publications from 2008 to 2017 based on the technology-enhanced learning model. Interactive Learning Environments, 27(8), 1011-1027. Available at: 10.1080/10494820.2018.1467462.

Lynch, D., Smith, R., Provost, S., Yeigh, T., \& Turner, D. (2017). The correlation between 'teacher readiness' and student learning improvement. International Journal of Innovation, Creativity and Change, 3(1), 1-12. 
Menon, S. (2020). Education ministry launches delima online learning platform. Retrieved from: https://www.thestar.com.my/news/nation/2020/06/16/education-ministry-launches-delima-online-learning-platform.

Merç, A. (2015). Using technology in the classroom: A study with Turkish pre-service EFL teachers. The Turkish Online Journal of Educational Technology, 14(2), 229-240.

Ministry of Education Malaysia. (2013). Malaysia education blueprint 2013-2025. Putrajaya: Ministry of Education Malaysia

Ministry of Education Malaysia. (2019). Google classroom (GC).

Ministry of Education Malaysia. (2020a). Media statement: Implementation of teaching and learning following the extension of movement control order period. Retrieved from: https://www.moe.gov.my/pemberitahuan/kenyataan-media/kenyataan-media-pelaksanaanpengajaran-dan-pembelajaran-berikutan-perlanjutan-tempoh-perintah-kawalan-pergerakan.

Ministry of Education Malaysia. (2020b). Media statement: Educational TV Program slot on OKEY TV channel, radio televisyen Malaysia (RTM). Retrieved from: https://www.moe.gov.my/pemberitahuan/kenyataan-media/kenyataan-media-slot-program-tvpendidikan-di-saluran-tv-okey-radio-televisyen-malaysia-rtm.

Moore, J. L., Dickson-Deane, C., \& Gaylen, K. (2011). E-Learning, online learning, and distance learning environments: Are they the same? The Internet and Higher Education, 14(2), 129-135. Available at: 10.1016/j.iheduc.2010.10.001.

Muslem, A., Yusuf, Y. Q., \& Juliana, R. (2018). Perceptions and barriers to ICT use among English teachers in Indonesia. Teaching English with Technology, $18(1), 3-23$.

Omar, A., Amir, Z., \& Mohamad, M. (2018). Facilitating online learning: students' online discussion strategies for a project work at a technical university in Malaysia. 3L: The Southeast Asian Journal of English Language Studies, 24(4), 102-114. Available at: 10.17576/3L-2018-2404-08

Philip, B., Tan, K. H., \& Jandar, W. (2019). Exploring teacher cognition in Malaysian ESL classrooms. 3L: Language, linguistics, literature®. Selangor: Publisher Universiti Kebangsaan Malaysia.

Razak, N. A., Alakrash, H., \& Sahboun, Y. (2018). English language teachers' readiness for the application of technology towards fourth industrial revolution demands. Asia-Pacific Journal of Information Technology and Multimedia, 7(2), 89-98.

Raziq, A., \& Maulabakhsh, R. (2015). Impact of working environment on job satisfaction. Procedia Economics and Finance, $23,717-725$. Available at: 10.1016/S22 12-5671(15)00524-9.

Saadé, R. G., \& Al-Sharhan, J. A. (2015). Discovering the motivations of students when using an online learning tool. Journal of Information Technology Education: Research, 14(1), 283-296.

Sahu, P. (2020). Closure of universities due to coronavirus disease 2019 (COVID-19): Impact on education and mental health of students and academic staff. Cureus, $12(4)$, e7541.

Salem, N., \& Mohammadzadeh, B. (2018). A study on the integration of ICT by EFL teachers in Libya. EURASIA Journal of Mathematics, Science and Technology Education, 14(7), 2787-2801. Available at: https://doi.org/10.29333/ejmste/90594.

Schmidt, D. A., Baran, E., Thompson, A. D., Mishra, P., Koehler, M. J., \& Shin, T. S. (2009). Technological pedagogical content knowledge (TPACK) the development and validation of an assessment instrument for preservice teachers. Journal of research on Technology in Education, 42(2), 123-149. Available at: https://doi.org/10.1080/15391523.2009.10782544.

Sundeen, T. H., \& Sundeen, D. M. (2013). Instructional technology for rural schools: Access and acquisition. Rural Special Education Quarterly, 32(2), 8-14. Available at: https://doi.org/10.1177/875687051303200203.

Tan, K. H., Philip, B., \& Jandar, W. A. (2019). Teacher Cognition in ESL context - a pedagogical perspective in Malaysian classroom. Selangor: Publisher Universiti Kebangsaan Malaysia.

Tan, P., \& Tan, K. (2020). In-game instructions: The extent of their usefulness in enhancing the vocabulary acquisition of ESL learners. International Journal of Emerging Technologies in Learning (iJET), 15(4), 73-89. Available at: https://doi.org/10.3991/ijet.v15i04.11647.

UNESCO. (2020). From disruption to recovery. Retrieved from: https://en.unesco.org/covid 19/educationresponse.

Ursachi, G., Horodnic, I. A., \& Zait, A. (2015). How reliable are measurement scales? External factors with indirect influence on reliability estimators. Procedia Economics and Finance, 20, 679-686. Available at: https://doi.org/10.1016/s22 12-5671(15)00123-9.

Venkatesh, V., \& Bala, H. (2008). Technology acceptance model 3 and a research agenda on interventions. Decision Sciences, 39(2), 273-315.

Wang, P.-Y. (2013). Examining the digital divide between rural and urban schools: Technology availability, teachers' integration level and students' perception. Journal of Curriculum and Teaching, 2(2), 127-139.

Zarzycka-Piskorz, E. (2016). Kahoot it or not? Can games be motivating in learning grammar? Teaching English with Technology, 16(3), 1736.

Zhang, W., Wang, Y., Yang, L., \& Wang, C. (2020). Suspending classes without stopping learning: China's education emergency management policy in the COVID-19 outbreak. Journal of Risk and Financial Management, 13(3), 1-6.

Zhang, Y., \& Ma, Z. F. (2020). Impact of the COVID-19 pandemic on mental health and quality of life among local residents in liaoning province, China: A cross-sectional study. Int. J. Environ. Res. Public Health, 17(7), 1-12.

Zhou, L., Li, F., Wu, S., \& Zhou, M. (2020). 'School's out, but class' on', the largest online education in the world today: taking china's practical exploration during the COVID-19 epidemic prevention and control as an example. Online Submission, 4(2), 501-519. 